Original Paper http://ajol.info/index.php/ijbcs http:/indexmedicus.afro.who.int

\title{
Diversity and enzymatic characterization of Bacillus species isolated from traditional cassava starters used for attiéké production
}

\author{
Abodjo Celah KAKOU ${ }^{1 *}$, Ollo KAMBIRE ${ }^{2}$, Zamble Bi Abel BOLI ${ }^{1}$, \\ Thierry Dezay YORO ${ }^{1}$, Nevry Rose KOFFI ${ }^{1}$ and Marina KOUSSEMON ${ }^{1}$ \\ ${ }^{1}$ Laboratory of Biotechnology and Food Microbiology; University of Nangui Abrogoua, \\ UFR/STA, 02 BP 801, Abidjan, Côte d'Ivoire. \\ ${ }^{2}$ Department of Biochemistry and Food Sciences, Peleforo Gon Coulibaly University, Côte d'Ivoire. \\ "Corresponding author; E-mail: kakoucelah@yahoo.fr
}

\begin{abstract}
Fermentation plays an important role in the production of cassava-based foods in West Africa. In Côte d'Ivoire, this step requires the use of a traditional cassava starter. Thus, the objective of this study was to identify and evaluate the enzymatic profile of the different Bacillus species present in these traditional cassava starters. Technique based on the analysis of the $16 \mathrm{~S}$ rDNA sequence was used for the identification of Bacillus species. Enzymatic activity of different species identified was carried out with API ZYM system. Based on the 16S r DNA sequence analysis, seven species of Bacillus (Bacillus subtilis, Bacillus cereus, Bacillus pumilus, Bacillus amyloliquefaciens, Bacillus methylotrophicus, Bacillus vallismortis and Bacillus toyonensis) were identified. $B$. subtilis was the most identified species with a frequency of $30 \%$ followed by $B$. amyloliquefaciens $(18 \%)$, B. methylotrophicus $(10 \%)$, B. cereus $(6 \%)$, B. toyonensis $(6 \%)$, B. vallismortis $(4 \%)$ and $B$. pumilus $(4 \%)$. Many of these species have been able to produce osidases, phosphatases, lipases and proteases. Seventeen enzymes from these different enzyme groups were synthesized by the identified Bacillus species. The dominant and enzyme-producing species could be used for the development of a starter culture. (C) 2017 International Formulae Group. All rights reserved.
\end{abstract}

Keywords: Bacillus species, enzymes, traditional cassava starter.

\section{INTRODUCTION}

Cassava (Manihot esculenta Crantz) is a major root crop in the tropics and its starchy roots are significant sources of calories for more than 500 million people worldwide (FAO, 2008). It is the fourth agricultural resource after rice, wheat and maize in the world (Koko et al., 2014). It has important agronomic advantages such as high yields in poor soils, resistance to drought and diseases. Cassava is traditionally processed into a wide variety of fermented products with different local names (attiéké, gari, fufu, agbelima, chikwangue placali, attoukpou) (Sahouegnon et al., 2014; Yao et al., 2015). The fermentation is controlled by several microorganisms, some of which have positive effects such as product preservation, flavor development, cyanide reduction and changes in functional properties.

In Côte d'Ivoire, the use of a traditional starter is required for the 
fermentation of cassava dough to make some of the different products referred to above. Its production varies according to ethnic group (Alladjan, Ebrié, Adjoukrou, Abouré) methods. Traditional starter processing method consists in cooking and fermenting the whole peeled cassava roots for 72 hours (Alladjan, Ebrié, Adjoukrou method). Another method to make the traditional starter is to use the whole unpeeled raw cassava roots and let it ferment (Abouré method) (Tetchi et al., 2012). These traditional starters were colonized by a wide variety of microorganisms which constitute the main source of microbial activities during the cassava dough fermentation (Djeni et al., 2008). Several studies have identified the microorganisms (lactic acid bacteria, yeast and moulds, Bacillus, coliforms and enterococci) associated to the traditional cassava starters (Kakou et al., 2010; Tetchi et al., 2012; Bouatenin et al., 2013 ; Kakou et al., 2016). Among the microflora, Bacillus genus plays an increasingly important role in food and industrial beverage (Grass et al., 2004). Different species of Bacillus can produce several important enzymes such as amylase, cellulase, tannase, pectinase and betaglucosidase (Schallmey et al., 2004; Oyeleke et al., 2011). In Côte d'Ivoire, studies have already shown the ability of Bacillus spp isolated from the traditional cassava starter to produce enzymes (Bouatenin et al., 2013; Ehon et al., 2015). However, any studies have been carried out on the different species of Bacillus colonizing these traditional cassava starters.

Thus, the objective of this research was to identify the different species of Bacillus from traditional starter (Alladjan, Ebrié,
Abouré) used for attiéké production and their enzymatic profile.

\section{MATERIALS AND METHODS}

Samples collection and isolation of Bacillus strains

The traditional cassava starters (Alladjan starters, Ebrié starters, Abouré starters) were collected in four cities of Côte d'Ivoire. The Ebrié starter were collected in Abidjan, Bouaké and Abengourou, the Abouré starters in Bonoua and the Alladjan starters in Abidjan. For the isolation of Bacillus strains, $10 \mathrm{~g}$ of each starter was homogenized with 90 $\mathrm{mL}$ of sterile buffer peptone water. Serial dilutions of the different samples were spread on a Plate Count Agar containing 1\% starch. For preliminary identification, bacterial colonies were isolated and characterized by their morphological properties and appearance. Fifty strains of Bacillus were isolated from the different traditional cassava starters for the species identification.

\section{Isolation of chromosomal DNA}

Chromosomal DNA was prepared from overnight culture on agar Mossel. Isolation and purification were conducted with a kit (Instagen Matrix Bio-Rad, USA) according to the manufacturer's instructions.

\section{S rDNA amplification}

To amplify the 16S rDNA gene, a primer pair (Table 1) hybridizing to two conserved regions was used for the identification of Bacillus strains. PCR mixture consisted of $0.2 \mathrm{mM}$ of each primer (16R1522 and 16F27), $20 \mu \mathrm{L}$ of $1 \mathrm{X}$ Master Mix(5PRIME Hot MasterMix 2,5X DOMINIQUE Dutscher, France), $1 \mu \mathrm{L}$ of DNA and $\mathrm{H}_{2} \mathrm{O}$ in a final volume of $50 \mu \mathrm{L}$. 
Table 1: Primers used for gene amplification.

\begin{tabular}{lccc}
\hline Primer name & Tm $\left({ }^{\circ} \mathbf{C}\right)$ & \%GC & Oligonucleotide (5'--- 3') \\
\hline 16R27 & 57,3 & 50 & AGAGTTTGATCCTGGCTCAG \\
16F1522 & 44,7 & 60 & AAGGAGGTGATCCAGCCGCA \\
\hline
\end{tabular}

Amplification conditions consisted of $94{ }^{\circ} \mathrm{C}$ initial denaturation for $2 \mathrm{~min}, 35$ cycles of 94 ${ }^{\circ} \mathrm{C}$ for $1 \mathrm{~min}, 58{ }^{\circ} \mathrm{C}$ for 30 seconds (hybridization), $65{ }^{\circ} \mathrm{C}$ for $2 \mathrm{~min}$ (extension) and final extension at $65{ }^{\circ} \mathrm{C}$ for $7 \mathrm{~min}$ before cooling at $4{ }^{\circ} \mathrm{C}$ in PCR thermocycler 2720 Thermalcycler type (AB Applied Biosystems, Syngapore). Ten (10) $\mu \mathrm{L}$ of the amplified products of PCR were analyzed by electrophoresis in $1 \%$ of agarose gel stained with ethidium bromide.

\section{Sequencing and phylogenetic analysis}

PCR products were purified and quantified by electrophoresis in $08 \%(\mathrm{w} / \mathrm{v})$ agarose gel. The 16S rDNA obtained was sent to the sequencing platform of Cochin Eurofins MW operon (France). DNA sequences were determined by chain-termination method (Sanger et al., 1977) using automatic ABI $3730 X 1$ sequencing kit 96 capillary DNA Analyzers. The sequences obtained were compared with sequences in the database of NCBI (National Center for Biotechnology Information) using the BLAST program. The taxonomic browser NCBI server (http://www.ncbi.nlm.nih.gov/blast) was helped to find the affiliation of strains.

\section{Enzymatic activities}

Enzymatic activity of Bacillus strains was performed using API-ZYM system according to the manufacturer's instructions. The results were analyzed with a reading table of API-ZYM system.

\section{RESULTS}

Figure 1 shows the electrophoretic profile of the 16S rDNA gene of Bacillus strains isolated from different types of traditional cassava starter. After the phylogenetic analyses based on the alignment of the nucleotide sequences, the percentages of homology were between 95 and 99\%. Bacillus subtilis was the most identified species with a frequency of $30 \%$ followed by B. amyloliquefaciens (18\%) and $B$. methylotrophicus (10\%) (Figure 2). The frequency of identification of $B$. toyonensis and $B$. cereus was $6 \%$ each. B. vallismortis and $B$. pumilus species with a frequency of $4 \%$ were the least identified. The frequency of unidentified species (Bacillus spp) was 22\%.

\section{Isolation frequencies of Bacillus species by site and type of traditional cassava starter}

Table 2 shows the different Bacillus species and their isolation frequencies in traditional cassava starter. B. subtilis and $B$. amyloliquefaciens were identified in the three types of traditional cassava starter from the five sites investigated. These two species predominated in the Ebrié starter of ABKOUTE site, with frequencies of $12 \%$ for $B$. subtilis and $4 \%$ for B. amyloliquefaciens. $B$. toyonensis, $B$. cereus and B. methylotrophicus were isolated from Ebrié starter of ABKOUTE and Abengourou, as well as in the Alladjan starter. B. vallismortis was isolated in the Ebrie and Alladjan starter whereas $B$. pumilus was found only in the Ebrié starter. 
Seven Bacillus species isolated in this work were identified in the Ebrié starter of Abengourou site.

\section{Enzymes produced by Bacillus species isolated from traditional cassava starters}

Table 3 shows the distribution groups of enzymes produced by Bacillus strains. Phosphatases (alkaline phosphatase, acid phosphatase, naphthol phosphohydrolase) were produced by $71 \%$ of the species, followed by lipase producing strains (esterases $\mathrm{C} 4$, lipase esterases $\mathrm{C} 8$, lipases $\mathrm{C} 14$ ), with a frequency of $66 \%$. Osidases (alphagalactosidase, beta-galactosidase, betaglucuronidase, alpha-glucosidase, betaglucosidase, N-acetyl-beta-glucosaminidase, alpha-mannosidase, alpha-fucosidase) were produced by $32 \%$ species. Proteases (leucine arylamidase, valine arylamidase, cystine arylamidase, trypsin, alpha-chymotrypsin) were the enzymes least expressed by Bacillus species with a frequency of $24 \%$. Table 4 indicates the enzymes produced by the Bacillus species isolated from traditional cassava starter. Among the nineteen enzymes sought, seventeen enzymes were produced by at least one or more Bacillus species whereas two enzymes, esterase (C4) and alphaglucosidase, were produced by all Bacillus species isolated. The enzymes alphafucosidase and $\alpha$-mannosidase were not produced by any species. A high percentage (90\%) of Bacillus isolated, produced betaglucosidase and esterase lipase, $82 \%$ produced alkaline phosphatase and $76 \%$ produced naptol phosphohydrolase.

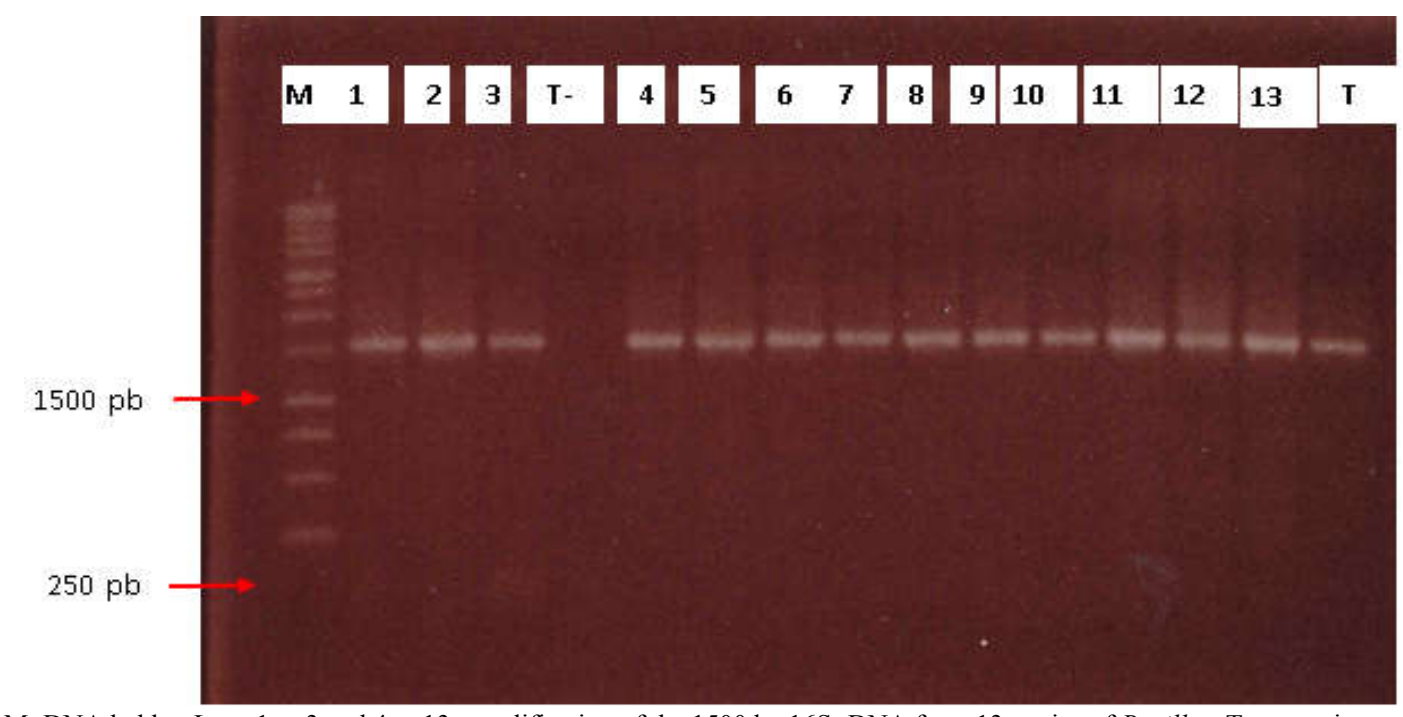

M: DNA ladder, Lane 1 to 3 and 4 to 13: amplification of the 1500 bp 16S rDNA from 13 strains of Bacillus, T- : negative control; $\mathrm{T}+$ positive control.

Figure 1: Electrophoretic profile of the 16S rDNA gene of Bacillus strains from traditional cassava starter. 


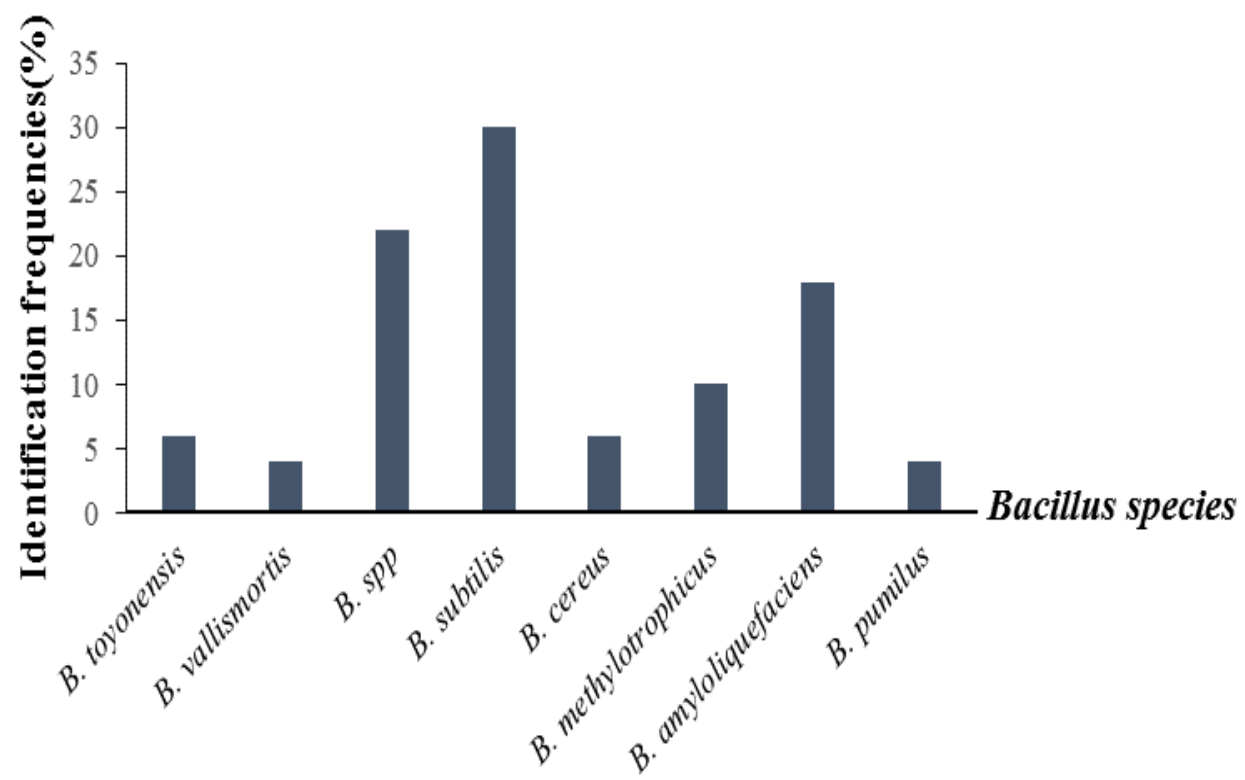

Figure 2: Isolation frequencies of Bacillus species from traditional cassava starter.

Table 2: Isolation frequencies of Bacillus species by site and type of traditional cassava starter.

\begin{tabular}{|c|c|c|c|c|c|}
\hline \multirow{3}{*}{$\begin{array}{l}\text { Types of starter } \\
\text { Sampling site }\end{array}$} & \multicolumn{5}{|c|}{ Identification frequencies } \\
\hline & \multicolumn{3}{|c|}{ Ebrié starter } & \multirow{2}{*}{$\begin{array}{c}\text { Abouré starter } \\
\text { BONOUA }\end{array}$} & \multirow{2}{*}{$\begin{array}{c}\text { Alladjan starter } \\
\text { AB-NG }\end{array}$} \\
\hline & ABENG & BOUAKE & AB-KOUTE & & \\
\hline \multicolumn{6}{|l|}{ Strains } \\
\hline B. toyonensis & $1(2 \%)$ & 0 & $1(2 \%)$ & 0 & $1(2 \%)$ \\
\hline B. vallismortis & $1(2 \%)$ & 0 & 0 & 0 & $1(2 \%)$ \\
\hline Bacillus sp & $2(4 \%)$ & $3(6 \%)$ & $2(4 \%)$ & $1(2 \%)$ & $3(6 \%)$ \\
\hline B. subtilis & $3(6 \%)$ & $2(4 \%)$ & $6(12 \%)$ & $1(2 \%)$ & $3(6 \%)$ \\
\hline B. cereus & $1(2 \%)$ & 0 & $1(2 \%)$ & 0 & $1(2 \%)$ \\
\hline B. methylotrophicus & $2(4 \%)$ & 0 & $1(2 \%)$ & 0 & $2(4 \%)$ \\
\hline B. amyloliquefaciens & $1(2 \%)$ & $2(4 \%)$ & $4(8 \%)$ & $1(2 \%)$ & $1(2 \%)$ \\
\hline B. pumilus & $1(2 \%)$ & $1(2 \%)$ & 0 & 0 & 0 \\
\hline
\end{tabular}

$\mathbf{N}=$ Number; F: Frequency 
Table 3: Groups of enzymes produced by Bacillus strains.

\begin{tabular}{|c|c|c|c|c|c|c|}
\hline \multirow[t]{3}{*}{ Types of starter } & \multicolumn{6}{|c|}{ Frequencies of Bacillus species (\%) } \\
\hline & \multicolumn{3}{|c|}{ Ebrié starter } & \multirow{2}{*}{$\begin{array}{l}\text { Alladjan } \\
\text { starter }\end{array}$} & \multirow[t]{2}{*}{ Abouré starter } & \multirow[t]{3}{*}{ Total } \\
\hline & \multicolumn{3}{|c|}{ Sampling site } & & & \\
\hline Enzyme groups & AB-KOUTE & BOUAKE & ABENG & AB-NG & BONOUA & \\
\hline Lipases & 21 & 10 & 15 & 17 & 3 & 66 \\
\hline Phosphatases & 20 & 12 & 17 & 17 & 5 & 71 \\
\hline Osidases & 11 & 4 & 8 & 8 & 1 & 32 \\
\hline Protéases & 9 & 2 & 5 & 7 & 1 & 24 \\
\hline
\end{tabular}

Table 4: Enzymes produced by Bacillus species isolated from traditional cassava starters.

\begin{tabular}{|c|c|c|c|c|c|c|}
\hline \multirow{4}{*}{$\begin{array}{l}\text { Types of starter } \\
\text { Sampling site } \\
\end{array}$} & \multicolumn{6}{|c|}{ Number and frequency of Bacillus strains [N(F)] } \\
\hline & \multirow{2}{*}{\multicolumn{3}{|c|}{ Ebrié starter }} & \multirow{3}{*}{$\begin{array}{l}\begin{array}{l}\text { Alladjan } \\
\text { starter }\end{array} \\
\text { AB-NG }\end{array}$} & \multirow{3}{*}{$\begin{array}{c}\text { Abouré starter } \\
\text { BONOUA }\end{array}$} & \multirow[b]{3}{*}{ Total } \\
\hline & & & & & & \\
\hline & AB-KOUTE & BOUAKE & ABENG & & & \\
\hline \multicolumn{7}{|l|}{ Enzymes } \\
\hline PAL & $10(20)$ & $8(16)$ & $10(20)$ & $10(20)$ & $3(6)$ & $41(82)$ \\
\hline EST & $15(30)$ & $8(16)$ & $12(24)$ & $12(24)$ & $3(6)$ & $50(100)$ \\
\hline ESTLIP & $14(28)$ & $8(16)$ & $9(18)$ & $12(24)$ & $2(4)$ & $45(90)$ \\
\hline LIP & $3(6)$ & $0(0)$ & $2(4)$ & $2(4)$ & $0(0)$ & $7(14)$ \\
\hline LEUAR & $9(18)$ & $2(4)$ & $8(16)$ & $8(16)$ & $3(6)$ & $30(60)$ \\
\hline VALAR & $5(10)$ & $0(0)$ & $1(2)$ & $3(6)$ & $0(0)$ & $9(18)$ \\
\hline CYSAR & $4(8)$ & $0(0)$ & $2(4)$ & $3(6)$ & $0(0)$ & $9(18)$ \\
\hline TRYP & $2(4)$ & $0(0)$ & $1(2)$ & $2(4)$ & $0(0)$ & $5(10)$ \\
\hline$\alpha-\mathrm{CHY}$ & $3(6)$ & $3(6)$ & $1(2)$ & $1(2)$ & $0(0)$ & $8(16)$ \\
\hline PAC & $8(16)$ & $8(16)$ & $9(18)$ & $6(12)$ & $2(4)$ & $33(66)$ \\
\hline NAPP & $12(24)$ & $7(14)$ & $7(14)$ & $10(20)$ & $2(4)$ & $38(76)$ \\
\hline$\alpha-G A L$ & $5(10)$ & $0(0)$ & $4(8)$ & $3(6)$ & $0(0)$ & $12(24)$ \\
\hline$\beta$-GAL & $7(14)$ & $0(0)$ & $5(10)$ & $5(10)$ & $0(0)$ & $17(34)$ \\
\hline$\beta-G L U C$ & $2(4)$ & $1(2)$ & $2(4)$ & $1(2)$ & $0(0)$ & $6(12)$ \\
\hline$\alpha-G L U$ & $15(30)$ & $8(16)$ & $12(24)$ & $12(24)$ & $3(6)$ & $50(100)$ \\
\hline$\beta$-GLU & $14(28)$ & $8(16)$ & $9(18)$ & $11(22)$ & $3(6)$ & $45(90)$ \\
\hline $\mathrm{NA} \beta \mathrm{G}$ & $1(2)$ & $0(0)$ & $1(2)$ & $1(2)$ & $0(0)$ & $3(6)$ \\
\hline$\alpha$-MAN & $0(0)$ & $0(0)$ & $0(0)$ & $0(0)$ & $0(0)$ & $0(0)$ \\
\hline$\alpha$-FUC & $0(0)$ & $0(0)$ & $0(0)$ & $0(0)$ & $0(0)$ & $0(0)$ \\
\hline
\end{tabular}

Enzymes : PAL: Phosphatase alcaline ; EST: Estérase (C4) ; ESTLIP : Estérase lipase (C8) ; LIP: Lipase (C14) ; LEUAR : Leucine arylamidase ; VALAR : Valine arylamidase ; CYSAR : Cystine arylamidase; TRYP : Trypsine ; $\alpha$-CHY: AlphaChymotrypsine ; PAC : Phosphatase acide ; NAPP : Naphtol phosphohydrolase ; $\alpha$-GAL : Alpha-galactosidase (mélibiase) ; $\beta$-GAL: Béta-galactosidase (lactase) $\beta$-GLUC : Béta-glucuronidase (hyaluronidase) ; $\alpha$-GLU : Alpha-glucosidase (maltase) ; $\beta$-GLU : Béta-glucosidase (cellulase) ; NA $\beta \mathrm{G}$ : N-acétyl-béta-glucosaminidase (chitinase) ; $\alpha$-MAN : Alpha-mannosidase ; $\alpha$-FUC : Alpha-fucosidase ; N: Number; F: Frequency. 


\section{DISCUSSION}

Seven species of Bacilllus have been identified from traditional starter of cassava analyzed, namely $B$. toyonensis, $B$. vallismortis, $B$. subtilis, $B$. cereus, $B$. methylotrophicus, B. amyloliquefaciens and $B$. pumilus. These species differ from those reported by Assanvo et al. (2002) in their study based on the microflora of the traditional starter of cassava for the production of attiéké in Dabou. Indeed, these authors reported three species of Bacillus, namely B. sphaericus, B. brevis, and $B$. coangulans. Contrary to these authors, the species identified in this study have been reported by other authors during the fermentation of cassava roots. B. subtilis, $B$. cereus, B. pumilus and B. amyloliquefaciens were identified by Amoa-Awua and Jakobsen (1995) during the process of the cassava roots fermentation. Bouatenin et al. (2013) identified the presence of $B$. amyloliquefaciens and $B$. cereus from Adjoukrou traditional cassava starter. Bacillus species can produce $\alpha$-amylase which can hydrolyze starch and release the sugars for the production of organic acids mainly lactic acid. B. subtilis $(30 \%)$ was the important isolate among the seven species identified in this study. This result corroborates those of Adewumi et al. (2009) during the production of gari and Azokpota et al. (2007). Bacillus are found to produce some products such as vitamin B3, B12, $\mathrm{K}$ and digestive enzymes such as amylase, protease, lipase (Tamehiro et al., 2002).

The enzymatic characterization of the different species in the present study has showed that these could produce osidases, phosphatases, lipases and proteases. The ability of Bacillus species to produce osidases during the cassava root fermentation has been reported by several authors including AmoaAwua and Jakobsen (1995), Bouatenin et al. (2013), Ehon et al. (2015). Indeed, these osidases are involved in the hydrolysis of starch and the release of simple sugars which are essential for the synthesis of organic acids.

Bacillus species have shown overall a good $\alpha$-glucosidase (100\%) and $\beta$-glucosidase (94\%) synthesis ability. $\beta$-glucosidase is the main enzyme responsible for the natural degradation of the cyanogenetic glucosides of cassava into glucose and acetone cyanohydrin (Djoulde et al., 2005). According to Mkpong et al. (1990), 65\% of homology was observed between $\beta$-glucosidase activity and that of linamarase. Concerning $\alpha$-glucosidase, it is involved in the hydrolysis of isomaltose resulting from the degradation of starch by $\alpha$ amylase.

Most of the species could produce phosphatases, contrary to the study of Parvathi et al. (2009) on the species of Bacillus pumilus isolated from the aquatic environment. The lipolytic and proteolytic activity of Bacillus species have been reported in various studies (Ouoba et al., 2003a; Ouoba et al., 2003b; Mo et al., 2010; May and AlAllaf, 2011). According to Azokpota et al. (2006), the proteolytic activity of Bacillus species enables them to contribute to the release of bioactive peptides which play a very important role in the enzymatic process during fermentation. Moreover, in potein-rich products, the proteolytic activity of the Bacillus species would be responsible of the pH increase (Steinkraus, 1984). According to NDir et al. (1997), the lipolytic activity of Bacillus spp has an impact on the organoleptic quality of the products. 


\section{Conclusion}

Seven species of Bacillus (Bacillus subtilis, Bacillus cereus, Bacillus pumilus, Bacillus amyloliquefaciens, Bacillus methylotrophicus, Bacillus vallismortis and Bacillus toyonensis) were identified from the three types of traditional starter. Bacillus subtilis was the most present among the seven species. Several species of Bacillus have shown a capacity to produce various enzymes notably osidases, phosphatases, lipases and proteases. Among the osidases, $\beta$-glucosidase and $\alpha$-glucosidase were the most produced by the species. All species were able to produce esterase (C4) and alpha-glucosidase enzymes. It should also be noted that some species have been able to produce up to 15 enzymes.

\section{COMPETING INTERESTS}

The authors declare that they have no competing interests.

\section{AUTHORS' CONTRIBUTIONS}

ZBAB Collected the traditional cassava starter samples; ACK, OK and TDY contributed to the performing of the experiments and writing of the manuscript; NRK and MK revised critically for important intellectual content. All authors read and approved the final manuscript.

\section{ACKNOWLEDGMENTS}

We are very grateful to the producers of traditional cassava starters and the head of the Microbiology Laboratory of CIAPOL. We wish to thank also Mr. GONDO.

\section{REFERENCES}

Adewumi GA, Quadri RA, Oguntoyinbo FA. 2009. Antibiotic sensitivity pattern of Bacillus species isolated from solid substrate fermentation of cassava for gari production. Afr. J. Microbiol. Res., 3(1): 840-843.

Amoa-Awua WKA, Jakobsen M. 1995. The role of Bacillus species in the fermentation of cassava. J. Appl. Bacteriol., 79: 250-256. DOI: 10.1111/j.1365-2672.1995.tb03134.x

Assanvo JB Agbo GN, Yen B, Coulin P, Fara, Z. 2002. La microflore du ferment de manioc pour la production de l'attiéké adjoukrou (Côte d'Ivoire). Rev. Inter. Sci. de la Vie et de la Terre, ${ }^{\circ}$ spécial: 286-299.

Azokpota P, Møller PL, Hounhouigan JD, Jakobsen M. 2007. Biodiversity of predominant Bacillus isolated from afitin, iru and sonru at different fermentation time. Int. J. Biol. Chem. Sci., 1(3): 211-222.

Azokpota P, Hounhouigan DJ, Nago MC. 2006. Microbiological and chemical changes during the fermentation of African locust bean (Parkia biglobosa) to produce afitin, iru and sonru, three traditional condiments produced in Benin. Int J. Food Microbiol., 107: 304309. DOI: $10.1016 /$ j.ijfoodmicro. 2005.10.026

Bouatenin JPKM, Djeni TN, Ouassa T, Zinieu E, Menan H, Dje KM. 2013. Characterization and enzyme activities of microorganisms from a traditional cassava starter used for the production of Adjoukrou attiéké (Côte d'Ivoire). J. Food Technol., 11(1): 4-13.

Djeni NT, N'guessan KF, Dadie AT, Dje KM. 2008. Impact of different rates of a traditional starter on biochemical and microbiological changes during the 
fermentation of cassava for attiéké production. Food, 2(2): 145-151.

Djoulde DR, Etoa FX, Essia NJJ, Mbofung CMF. 2005. Screening des microorganismes à potentialités fermentaires pour le manioc. Tropicultura, 23(1): 11-18.

Ehon AF, Krabi RE, Assamoi AA, Niamke SL. 2015. Preliminary technological properties assessment of Bacillus spp. isolated from traditional cassava starters used for attieke production. European Scientific Journal, 11(9): 177-187.

FAO. 2008. The impact of HIV/AIDS on the agricultural sector. Corporate Document Repository, http://www.fao.org/ docrep/005/Y4636E/y4636e05.htm.

Grass G, Schierhorn A, Rucknagel P, Fricke B. 2004. Camelysin Is a novel surface metalloproteinase from Bacillus cereus infection and immunity. Infect. Immun., 72(1): 219-228.

DOI:

10.1128/IAI.72.1.219-228.2004

Kakou AC, Tagro GS, Olo K, Kouame AF, Koffi NR, Koussemon MC. 2010. Biochemical and microbial changes during traditional spontaneous lactic acid fermentation process using two varieties of cassava for production of a "Alladjan" starter. Int. Food Res. J., 17: 563-573.

Kakou AC, Toka DM, Kambire O, Koffi NR. 2016. Assessing the microbiological and chemical characteristics during traditional cassava starter "ebrié" production. J. Agri-Food \& Appl. Sci., 4(3): 53-59.

Koko CA, Benjamin KK, Blanchard YA, Georges NA, Assidjo EN. 2014. Comparative study on physicochemical characteristics of cassava roots from three local cultivars in Côte d'Ivoire.
European Scientific Journal, 10(33): 418-32.

May A, Al-Allaf A. 2011. Isolation of Bacillus spp. from some sources and study of its proteolytic activity. Tikrit Journal of Pure Science, 16(4): 5p.

Mo AY, Kwon B, Kamala-Kannan S, Lee KJ, Oh BT, Kim DH, Yang MS, Kim JH, Park SM. 2010. Isolation and characterization of Bacillus polyfermenticus isolated from Meju, Korean soybean fermentation starter. World J. Microbiol. Biotechnol., 26: 1099-1105. DOI:10.1007/s11274-009. 0276-Z

Mpong OE, Yan H, Chism G, Sayre RT. 1990. Purification, characterization and localisation of linamarase in cassava. Plant Physiol., 93: 176-181. DOI: http:// dx.doi.org/10.1104/pp.93.1.176

NDir B, Gningue RD, Keita NDG, Souane M, Laurent L, Cornelius C, Thonart Ph. 1997. Caractéristiques microbiologiques et organoleptiques du nététu $\mathrm{du}$ commerce. Cah. Agric., 6: 299-304.

Ouoba LII, Rechinger KB, Diawara B, Traoré AS, Jakobsen M. 2003a. Degradation of proteins during the fermentation of African locust bean (Parkia biglobosa) by strains of Bacillus subtilis and Bacillus pumilus for production of Soumbala. J. Appl. Microbiol., 94: 396402. PMID: 12588548

Ouoba LII, Cantor MD, Diawara B, Traoré AS, Jakobsen M. 2003b. Degradation of African locust bean oil by Bacillus subtilis and Bacillus pumilus isolated from soumbala, a fermented African locust bean condiment. J. Appl. Microbiol., 95(4): 868-873. DOI: 10.1046/j.1365-2672.2003.02063.x 
Oyeleke SB, Ibrahim AD, Manga SB, Rabah AB, Auta H Ladan F. 2011. Production of bacterial amylase by Bacillus species isolated from rice husk dumpsites in Sokoto metropolis, Nigeria. Int. J. Biol. Chem. Sci., 5(1): 380-385.

Parvathi A, Kiran K, Jiya J, Neetha J, Santha N. 2009. Biochemical and molecular characterization of Bacillus pumilus isolated from coastal environment in cochin, India. Braz. J. Microbiol., 40: 269-275.

Sahouegnon HH, Mitchikpe EC, Kayode APP, Dossa RAM. 2014. Contribution du manioc à l'alimentation et à la nutrition des enfants dans la commune de Djidja au Bénin. Int. J. Biol. Chem. Sci., 8(4): 1757-1770. DOI: http://dx.doi.org/10.4314/ijbcs.v8i4.34

Schallmey M, Singh A, Ward OP. 2004. Developments in the use of Bacillus species for industrial production. Can. $J$. Microbiol., 50: 1-17. DOI: 10.1139/w03076

Steinkraus KH. 1984. Solid-state (solidsubstrate) food/beverage fermentation involving fungi. Acta Biotechnol., 4(2): 83-88. DOI: 10.1002/abio.370040202

Tamehiro N, Okamoto-Hosoya Y, Okamoto $\mathrm{S}$, Makoto U, Masa H, Hiroshi N. et al. 2002. Bacilysocin a novel phospholipid antibiotic produced by Bacillus subtilis 168. Antimicrob Agents Chemother. 46(2): 315-320. PMCID: PMC 127064

Yao AK, Koffi DM, Blei SH, Irié ZB Niamke SL. 2015. Propriétés biochimiques et organoleptiques de trois mets traditionnels ivoiriens (attiéké, placali, attoukpou) à base de granulés de manioc natifs. Int. J. Biol. Chem. Sci., 9(3): 1341-1353. DOI: http://dx.doi.org/1 0.4314/ijbcs.v9i3.19 